\title{
THE RELIGIOUS IMAGERY OF THE JEHOVAH'S WITNESSES. LANDMARKS OF AN AMBIVALENT RELATIONSHIP WITH MODERNITY AND POSTMODERNITY
}

\author{
Radu Petre MURESAN*
}

\begin{abstract}
It is common knowledge that Jehovah's Witnesses reject the veneration of icons, which they equate with idol worshipping, while the Kingdom Halls do not contain any religious image or representation (icon, statue, religious painting). This aniconic attitude, however, is not consistent. Jehovah's Witnesses' publications are abundantly illustrated with biblical characters or episodes, eschatological representations, as well as pictures intended to reveal the stark contrast between their own ideal world, and the corrupted world outside their organization. This imagery seems to have a utilitarian purpose, rather than an aesthetic one, aiming mainly to create strong (positive or negative) emotions able to serve the aims of the organization. The present study aims to investigate, by means of images, the manner in which Jehovah's Witnesses describe themselves and their doctrine, as well as their position in relation to mainstream society and its values. We shall examine illustrations from recent publications issued by the Jehovah's Witnesses, as well as the official Romanian-language website of the organization, in order to reveal the common themes embraced by its imagery, to identify its stereotypes and clichés, and to analyze the dynamics of the interplay of identity and alterity.
\end{abstract}

Keywords: Jehovah's Witnesses, religious imagery, religious alterity, postmodernism

In 2006, when I defended my $\mathrm{PhD}$ thesis dwelling on the

* PhD, Rev., Associated Professor, University of Bucureşti (Faculty of Othodox Theology). 
Adventist-millenarian movements and their impact on contemporary society, the Jehovah's Witnesses Organization evinced the typical characteristics of a sect, according to the classical typology put forth by sociologist Bryan Wilson (1926-2004) ${ }^{1}$. Some sociologists remarked that the organization had engaged, although shyly, in a process of accommodating mainstream views on military service, blood transfusions, humanitarian aid, etc ${ }^{2}$. At the time, the official website of the Jehovah's Witnesses provided minimal information on the history and doctrine of the organization, which were presented in a dull way, unable to catch the interest of possible visitors.

Ten years later, I found Jehovah's Witnesses publications, as well as the new layout and design of their official website, revealed the fact that they had reinvented themselves. I discovered an astonishing change in their strategy, demonstrating that the organization still has the resourcefulness and the ability to play a significant role in the religious arena, despite the pessimistic expectations of sociologists and experts in the study of New Religious Movements. A few years ago, many of them used to think that 'classical' religious groups such as Jehovah's Witnesses had reached the height of their success on the religious market, and had ceased to appear attractive. In their opinion, door-to-door missionaries would certainly become ineffective as they were challenged by new religious and spiritual alternatives, and their fate would resemble that of peddlers or small retailers who had been 'crashed' by the emergence of supermarkets and shopping malls ${ }^{3}$.

In this context, I would like to make three points regarding the way in which the organization has improved its look by using visual tools. Firstly, Jehovah's Witnesses have ceased to proselytise exclusively by door-to-door preaching. Over the last three or four years, groups of Jehovah's Witness volunteers standing in busy city areas, displaying their brochures and publications, have become a common sight. This tactic allowing people to take the initiative, to ask for information on the

${ }^{1}$ Bryan WILsON, "Typologie des sectes dans une perspective dynamique et comparative", in Archive de Sociologie des Religions, no. 16/1963, p. 49-63.

${ }^{2}$ Regis DeRICQUeBOURG, “Les Temoins de Jehovah: vers une sortie de la logique sectaire?", in Françoise Champion (ed.), Sectes et democratie, Editions du Seuil, 1999, p. 105-126.

3 James LEwIS, "The Growth of Scientology and the Stark Model of Religious Success", in James R. Lewis (ed.), Scientology, Oxford University Press, 2009, p. 117-140 (p. 134). 
movement, to ask for a brochure, seems completely opposed to house-tohouse visits - is a token of the changes I was describing ${ }^{4}$. Most of the time, they are young persons who wait quietly for the passers-by to approach them. Their silent, smiling attitude leaves quite an impression, creating the image of a group where young people are the majority.

Secondly, I remembered that in 2006 the Jehovah's Witnesses launched the film 'Knocking', directed by Joel Engardio (who was raised as a Jehovah's Witness by his mother), focusing on the lives of two Jehovah's Witness families, and aiming to show how the members of this organization can reconcile the practices of a conservative religion, with the surrounding world. The film, which can be watched on the internet, is so emotional that viewers empathize with Jehovah's Witnesses, who are presented as martyrs for their faith and as tireless preachers of their Gospel message ${ }^{5}$.

This cinematic production was launched one hundred years after the release of another film, 'The Photo-Drama of Creation' (1914), by means of which Charles Russell (1852-1916), the leader of the Bible Student movement (the former name of Jehovah's Witnesses) made this movement known worldwide. Scholars regard the 'Photo-Drama' as the first major motion-picture production where sound recording (speech) was synchronized with motion pictures and color slides, projected by a diascope (Photo 1) ${ }^{6}$. At the time, cinematography was only at its beginnings, but Russell was a visionary who realized that the new invention could convey the message of the Bible Students better than any printed materials. Not surprisingly, those who were watching a film with sound for the first time were very impressed. In the first year alone, the film had almost nine million viewers in North America, Europe, Australia and the New Zealand.

4 On "trolley/cart witnessing" see BBC Magazine article "The Jehovah's Witnesses' new tactic", July 8, 2014 (http://www.bbc.com/news/magazine-28166192, accessed April 22, 2017).

${ }^{5}$ Knocking won several film festival awards including Best Documentary at the USA Film Festival. See Lisa Miller, "Belief watch: Jehovah's Witnesses", in Newsweek Magazine, May 27, 2007 (http://www.newsweek.com/beliefwatch-jehovahs-witnesses-101091, accessed April 22, 2017).

${ }^{6}$ The Watchtower study edition of February 2014 celebrates "A 100-Year-Old Epic of Faith", providing some interesting technical details (p. 30-32). 
The most important change in attitude, however, is revealed by the official website (in Romanian) which - like any other version in a foreign language - is an accurate translation of the official website in English. This change was announced in the January 2013 issue of the 'Watchtower' where we learned of the organization's awareness that increasingly many people seek information on the Internet; consequently, the official website has been altered to make it "more appealing and easier to navigate" . Indeed, the current website of the Jehovah's Witnesses is user-friendly, attractive, richly illustrated, and designed to gain converts. Any visitor who happens to access this website can ask for free home Bible study, learn about the nearest Kingdom Hall, find the date of the Memorial of Jesus' Death they can attend, or receive details on the next District or Regional Convention ${ }^{8}$.

A novelty I have noticed is that it is possible to tour the nearest branch office of the organization - a marketing strategy very similar to that employed by the great candy factories that provide free tours to the children in schools and kindergartens, in order to turn them into regular buyers. There are also numerous applications (JW Library, JW Language) designed for Android, iPad, iPhone and iPad touch that allow adherents or visitors of the website to find Jehovah Witness books or brochures, learn a foreign language, or develop the communication skills necessary for preaching or managing the weekly meetings. Parts of the official website are translated into sign languages, for the benefit of disabled persons ${ }^{9}$.

In one of the most recent works on Jehovah's Witnesses, Professor Chrysidess noted that the official website of the organization is designed to address young persons and children ${ }^{10}$. Indeed, the Bible Teachings section includes two subsections: Bible Questions Answered, presenting the doctrinal tenets of the organization, and Help for the

${ }^{7}$ The Watchtower, January 2013, p. 3.

${ }^{8}$ https://www.jw.org/en, accessed April 22, 2017.

9 One 2016 issue of Awake! magazine triumphantly announced that Jehovah's Witnesses Organization had broken the language barrier, being translated into 750 languages and 80 sign languages (Awake! no. 3/2016, p. 16).

${ }^{10}$ George D. CHRYSSIDES, Jehovah's Witnesses: Continuity and Change, Routledge, 2016, p. 155: "The recently designed jw.org website has pages specifically targeted at teenagers and children". 
Family, which, in turn, is divided into three categories: Couples and Parents, Teenagers, and Children, respectively. Under the heading Couples and Parents are articles from older or more recent publications, tackling various topical issues. In the case of teenagers, a similar rule is applied: questions raised by young people receive answers taken from recent publications. We note that these journals tackle, boldly and without inhibitions (an attitude never envisaged a few years ago), all the questions young people may have on sex, morals and love, friendship, family, school, health, personal identity, and recreation.

In this context, it is worth noticing the conservative manner in which subjects are illustrated. For the question concerning the harmful effects of pornography, the answer is provided by a comparison to smoking: „Pornography does to your mind what smoking does to your lungs. It pollutes you. It degrades something that God created to be a powerful and lasting bond between two people. In time, it can even cause you to become callous to what is right and wrong". However, the picture selected to illustrate this teaching is not related to the subject-matter, as one might expect, but to the comparison - it depicts the lungs of a smoker ${ }^{11}$ (Photo 2).

The section dedicated to children evinces the most innovative approach. In their case, the Jehovah's Witness doctrine is presented via videos lasting one minute - one minute and a half, where two nice kids Andrei and Iulia - teach children moral principles through storytelling: do not lie; be altruistic; be respectful to the house of Jehovah; pay attention at meetings; be generous and you will be happy; obey Jehovah, etc $^{12}$. The most interesting aspect is the pedagogical way in which these cartoons are made, as well as the fact that the teachings are driven home through songs and appropriate activities for preschoolers and pupils (coloring, cutting, collage, painting, etc). The organization clearly receives counselling on communication, marketing and advertising, and the visuals intended for children are designed by education experts.

Thus, the organization surprises us by their original attitude

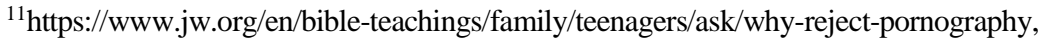
(accessed April 22, 2017).

12 https://www.jw.org/en/bible-teachings/family/children/become-jehovahs-friend/, (accessed April 22, 2017).
} 
towards children and youth, taking advantage of today's mass-media and communication technologies. Actually, one hundred years after its foundation, the organization has returned to the methods of Charles Taze Russell, who knew how to exploit the strides made by civilization in his times; namely, the railway network, new printing techniques and the invention of the cinema ${ }^{13}$.

The following part of the present study deals with the characteristics of illustrations found in their publications. I have examined the monthly issues of 'The Watchtower' and 'Awake!' magazines, respectively, published between 2010-2016, as well as recent Jehovah's Witness literature of interest for the present study.

Generally, Jehovah Witness publications target adults, without neglecting the young ones. Some issues of 'The Watchtower' have pages specially designed for preschoolers or pupils, using biblical stories as background for activities related to that specific age (Photo 3). Other issues of the magazine include the section 'Teach Your Children', presenting Old Testament stories from which the young can derive conclusions for current situations. However, the Witnesses prefer to address the young via modern media, which the young themselves use most. The cover of the December 2015 issue of the 'Watchtower' shows a group of Witnesses happily reading the Bible in various languages. Among them, a young girl is doing the same, but using her cell phone, while a young boy is using his iPad (Photo 4).

To ascertain the specific character of the illustrations present in Jehovah's Witness publications, I have decided to group them according to their topics, since they reflect the main features of the organization, as they have been defined sociologically. According to sociological surveys, the Jehovah's Witness Organization identifies itself as a group that is eschatological, millenarian, utopian, elitist, and mildly radical in its protest against the surrounding world ${ }^{14}$.

${ }^{13}$ Regis DerICQUEBOURG, "The Rise of Prophetism in Industrial Society: Market Rationality and the Economy Charisma. A propos de Charles Russell" in Chris Vonk (ed.), The Jehovah's Witnesses in scholarly perspective: What is new in the scientific study of the movement?, Acta comparanda, subsidia III, Faculty for Comparative Study of Religions and Humanism, Antwerpen, 2016.

14 IDEM, "La place des témoins de Jéhovah dans les groupes sectaires d'après leurs écrits officiels”, in Mélanges de Science Religieuse, no.2/1981, p. 127-132. 
A significant proportion of the illustrations reflect the fact that Jehovah's Witnesses are an eschatologically-oriented group, avidly awaiting and anticipating the end of the world and the destruction of this 'evil' state of affairs, this 'wicked system'. Without going into the complicated details of the Jehovah's Witness doctrinal tenets, but simply to understand the illustrations, it is worth noting that 1914 - the date of an erroneous prediction announcing the end of the world - has been reinterpreted as the date when Christ was enthroned in heaven and took office as king, while Satan was thrown down on earth. Satan is responsible for all deviant behaviors in society, and for all natural and human disasters (earthquakes, famine, diseases, wars) which will occur with increasing intensity until the Armageddon war. Among these 'signs of the times' proving that 'the end is near', one can see how the Witnesses identify themselves with the Good News of the God's Kingdom which will be preached worldwide (Photo 5) ${ }^{15}$.

The Armageddon war will be the natural consequence of the fact that "nations refuse to acknowledge God's sovereignty" 16 . It will be a terrible time, and Jehovah's Witnesses insist that those who are not part of their organization will die in extremely painful ways. Consequently, the illustrations are meant to instill fear and dread of this moment, through images reminiscent of the apocalyptic films. For instance, 'The Watchtower' issue of January 2016 shocked its readers with a striking picture. The title (Should we fear the end of the world?) is set against a background where fire balls are raining on a city, while terror-struck people are running for safety (Photo 6). Although it is clearly implied that there will be piles of corpses of the unbelievers destroyed by the Armageddon, their message is perceived as optimistic. The cover of 'The Watchtower' issue of May 2015, shows the Armageddon survivors making their way through the collapsed buildings while, in another picture, a group of Witnesses are heading for the earthly Paradise, bearing no traces of blood or dirt, but all looking sparkling clean (Photo 7).

What is this paradise to be installed on earth? All Jehovah's Witness publications describe it in the most attractive way possible. Sociologists have remarked that the Jehovah's Witness paradise is

${ }^{15}$ The Watchtower, no. 2/2016, p. 12-13.

${ }^{16}$ The Watchtower, September 2011, p. 10. 
actually a 'monde à l'invers': it offers hope to all those who are now underprivileged or marginalized, promising there will be no more ailing or sick people, no more disabled ones, no poorer or socially vulnerable persons, while their beloved deceased will be resurrected in their physical bodies ${ }^{17}$. The images depicting this utopian paradise are brightly colored making the viewer long for that place (Photo 8).

Secondly, this paradise will be home to an 'international brotherhood'; that is, it will be populated by people of all races. This frenzy of 'unity in diversity' is expressed by many compositions depicting life in paradise (Photo 9), as well as photos of graduates from the Bible School and the maps showing they come from all over the world. As the publications used to state, to Jehovah the color of one's skin or one's facial features do not matter at all; instead, he values one's heart, one's inward being ${ }^{18}$.

Jehovah's Witnesses have been described as an elitist group, for they perceive themselves as the only organization God wants to have on earth, and the only one in possession of the truth. As a result, they come to think that the world is divided into members of the organization and those outside it. The organization obsessively reminds adherents that anyone, but especially the young can become victims of 'bad associations', and provides examples set by Old Testament persons who stayed 'loyal to Jehovah' under difficult circumstances. One issue of 'The Watchtower' tackles the case of Jotham, son of Uzziah, who remained faithful to Jehovah while his father became estranged from God. Children are invited to ask themselves: "What about you? Would you keep on serving Jehovah even if your father or mother did not? This is a good question to ask yourself' (Photo 10) ${ }^{19}$.

17 "Will it not be thrilling to wake up each morning and realize that you now enjoy vibrant health? Will it not be gratifying for elderly persons to know that they have been restored to the full vigor of youth and will achieve the perfection that Adam and Eve originally enjoyed?... Great will be the joy earth wide when group after group of dead persons come back to life to join their loved ones! No longer will there be obituary columns to bring sadness to the survivors. Instead, there may well be just the opposite: announcements of newly resurrected ones to bring joy to those who loved them. So no more funerals, funeral pyres, crematoriums, or cemeteries!", Does God Really Care About Us?, Watch Tower Bible and Tract Society 2001, p. 23-25.

18 The Watchtower, July 2013, p. 23.

${ }^{19}$ The Watchtower, December 2012, p. 28-29. 
Elitism is also demonstrated by the tales of election; that is, the testimonies of converts. Almost every issue of 'The Watchtower' I have examined, under the heading of 'The Bible Changes Lives', presents testimonies of converts turned Witnesses after a previous time spent in a disorderly life. There are former drug addicts, rock music lovers, nightclubbers, alcoholics, homeless persons, members of criminal groups and gangs, etc. There is always a picture of the person before and after conversion. The contrast is as stark as the advertisements for weight loss products, where the image of an overweight person is juxtaposed with the transformed, slim figure of the same, having taken the respective pills (Photo 11).

Also, Jehovah's Witnesses are known for their radicalism in opposing other religions. Jehovah's Witnesses name any religion 'the Great Babylon', a phrase employed in the Book of Revelation, and ostentatiously applied to the Roman Catholic Church in particular. The July 2013 issue of the The Watchtower, whose cover subject is: "Is Any Religion Deserving of Trust?" states that anyone can ascertain whether they profess the true religion, by examining its position towards money, wars, and morals. Another article "Should You Be Charged for Religious Services?"20 is illustrated with the picture of a couple preparing for marriage, offering an envelope containing money to a Roman Catholic priest, while the adjoining picture shows Jesus overturning the tables of the merchants in the Temple (Photo 12).

The manner of illustrating Jehovah's Witness publications is based on several techniques, devices and methods aimed at making their point more effectively, maintaining the loyalty and commitment of members, and supporting evangelism. Firstly, I have remarked that their imagery is structured around the notion of contrast, of striking opposition able to create a powerful, lasting impression. The vibrantly colored illustrations depicting the smiling and blissful Witnesses, contrast with the black-andwhite or dully-colored illustrations presenting the corrupt world of those who steal, murder, or lead promiscuous lives (Photo 13).

Similarly, there is an equally stark contrast between the (often unfair) realities of today's world, and the promised state of affairs in paradise. The article "God's Kingdom - What Can It Mean For You?" is

${ }^{20}$ Awake!, June 2010, p. 22-23. 
illustrated with the picture of a man in a wheelchair, dully colored almost in black and white - while the same man, running happily in the paradise, is rendered in very bright colors; the pain caused by the loss of a dear one is contrasted to the joy felt on meeting the same person in paradise; the hopeless life of a homeless person is contrasted to the joy felt in paradise where everybody has a job (Photo 14) ${ }^{21}$.

I would also like to draw attention to the technique of image juxtaposition, intended to convey a particular message. The May 2010 issue of the 'The Watchtower' shows Jesus talking to a man, while the picture beside it shows a Jehovah's Witness discussing with a man and reiterating the gesture of Jesus - placing his hand on the interlocutor's shoulder. On the next page, one can see an image depicting Jesus' baptism adjoining a picture of the baptism of a Witness (Photo 15). Actually, one picture mirrors the other, and the text reinforces the notion of continuity between the age of early Christianity and contemporary Witnesses:

"Jesus taught his followers to share the good news... If you have learned about God's Kingdom and believe what the Bible says, you will doubtless enjoy sharing what you know. Many followers of Jesus start by speaking about God's Kingdom to their relatives"22.

The aim of the present study has been to demonstrate by means of visual illustrations that the relationship maintained by Jehovah's Witnesses with the surrounding world is ambiguous and paradoxical. On the one hand, Jehovah's Witnesses condemn the world governed by Satan, but, on the other hand, they make ample use of all the acquisitions of modern and postmodern technology and civilization, in order to achieve their goals. On the one hand, they reject the veneration of icons, which they see as tantamount to worshipping idols; on the other hand, they exploit visuals either in their printed literature, or via the Internet. Our conclusion is that Jehovah's Witnesses have not yet spoken their last word in the religious arena, and the manner in which they address children and youngsters still holds many surprises for the future.

${ }^{21}$ The Watchtower, October 2014, p. 6-7.

22 The Watchtower, May 2010, p. 17. 


\section{References}

1. *** Awake!, Watch Tower Bible and Tract Society (2010-2016)

2. *** Does God Really Care About Us, Watch Tower Bible and Tract Society, 1995, 2001

3. *** The Watchtower, Watch Tower Bible and Tract Society (20102016)

4. CHRYSSIDES, George, Jehovah's Witnesses. Continuity and change, Ashgater, 2016.

5. DERICQuebourG, Régis, "La place des témoins de Jéhovah dans les groupes sectaires d'après leurs écrits officiels", in Mélanges de Science Religieuse, no.2/1981, p. 127-132.

6. DericQuebourG, Régis, "Les Témoins de Jéhovah et le rapport d'enquête parlementaire", in Massimo Introvigne et J. Gordon Melton (eds.), Pour en finir avec les sectes, Milan, Cesnur-Di Giovanni, 1996, p. 255-260.

7. DericQuebourg, Régis, "Les Temoins de Jehovah: vers une sortie de la logique sectaire?", in Francoise Champion (ed.), Sectes et democratie, Editions du Seuil, 1999, p. 105-126.

8. Holden, Andrew, Jehovah's Witnesses. Portrait of a contemporary religious movement, London, 2002.

9. LEWIS, James, "The Growth of Scientology and the Stark Model of Religious Success", in James R. Lewis (ed.), Scientology, Oxford University Press, 2009, p. 117-140.

10. Vonk, Chris (ed.), The Jehovah's Witnesses in scholarly perspective: What is new in the scientific study of the movement?, Acta comparanda, subsidia III, Faculty for Comparative Study of Religions and Humanism, Antwerpen, 2016

11. WILSON, Bryan, Typologie des sectes dans une perspective dynamique et comparative, in "Archive de Sociologie des Religions", no. 16/1963, p. 49-63.

\section{Web sources:}

1. https://www.jw.org/en, (accessed April 22, 2017) 


\section{THE LIST of ILLUSTRATIONS}

Photo 1

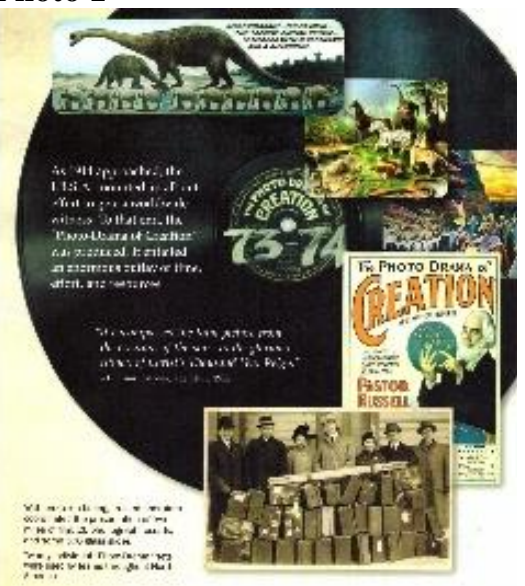

Photo 4

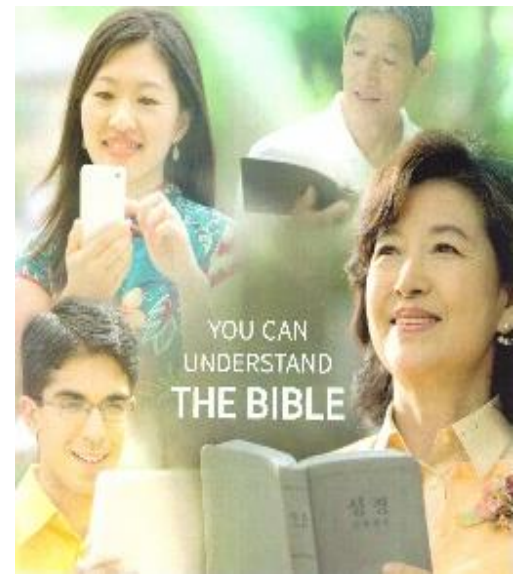

Photo 2

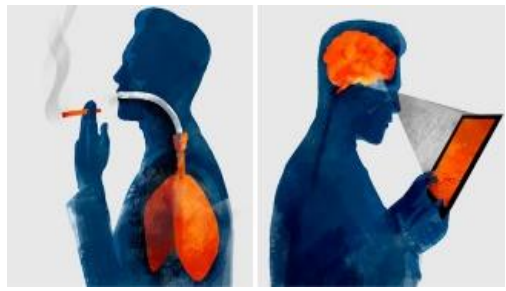

\section{Photo 3}

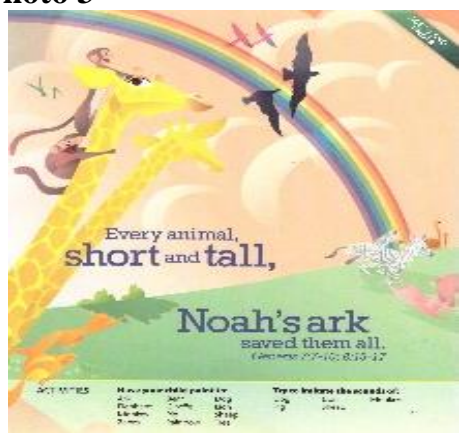

Photo 6

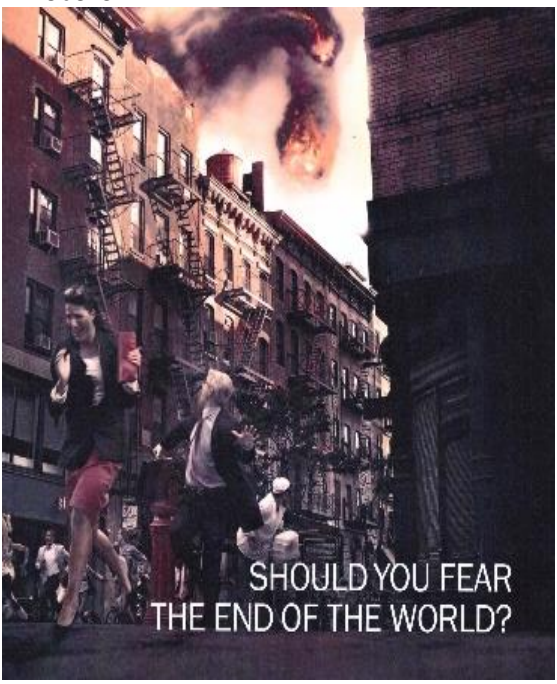


ARS LITURGICA. From the Image of Glory to the Images of the Idols of Modernity

\section{Photo 5}

DRAMATIC WORLD EVENTS SIGNALING THAT THE END IS NEAR

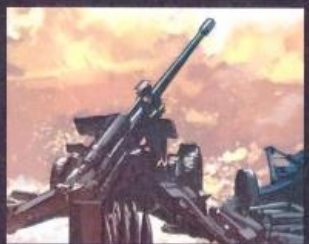

GLOBAL WAR AND ESCALATING CHAOS

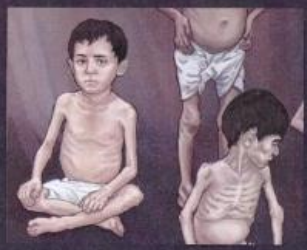

DISEASE AND HUNGER WORLDWIDE

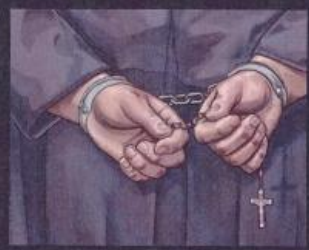

WIDESPREAD LAWLESSNESS AND RELIGIOUS CONFUSION

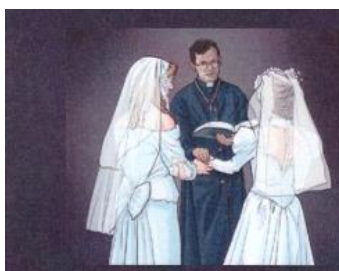

MORAL AND SOCIAL BREAKDOWN ON AN UNPRECEDENTED SCALE

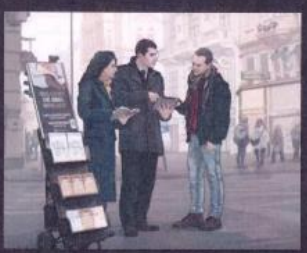

GOOD NEWS OF GOD'S KINGDOM PREACHED WORLDWIDE

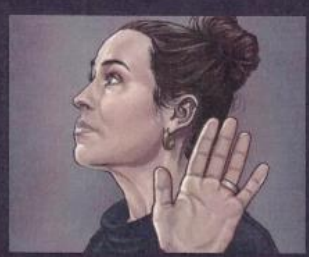

CRITICS DENY THAT THE END IS NEAR

\section{Photo 7}
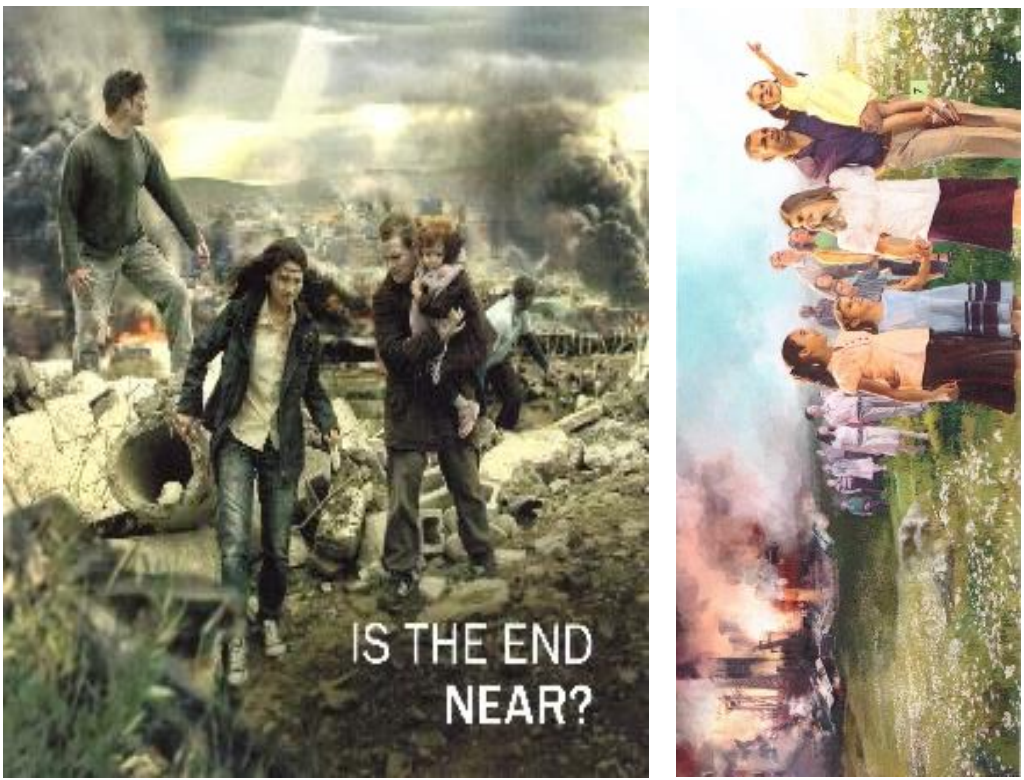


\section{Photo 8}

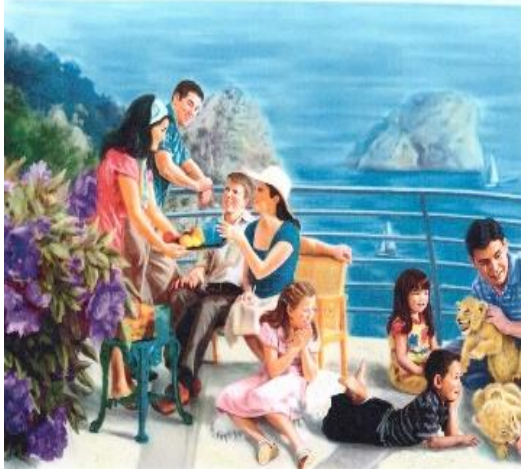

\section{Photo 10}
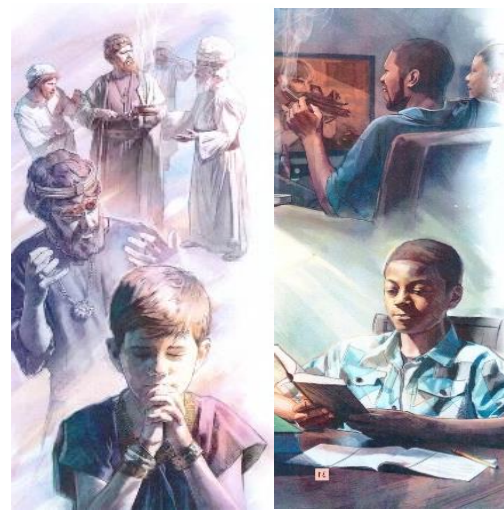

Photo 12

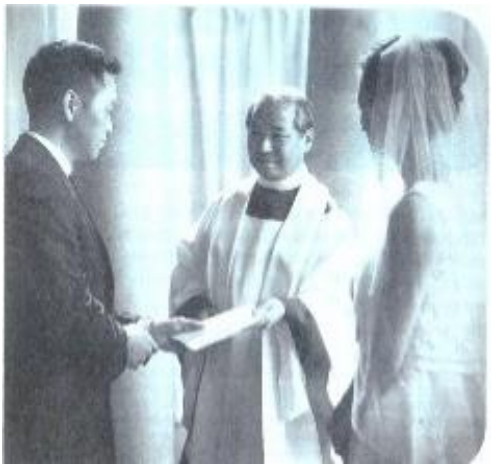

\section{Photo 9}

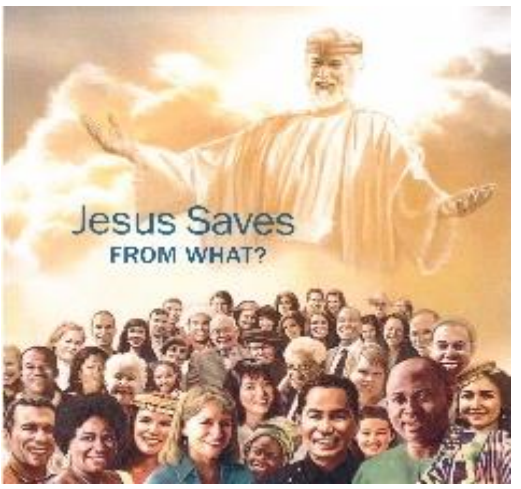

\section{Photo 11}
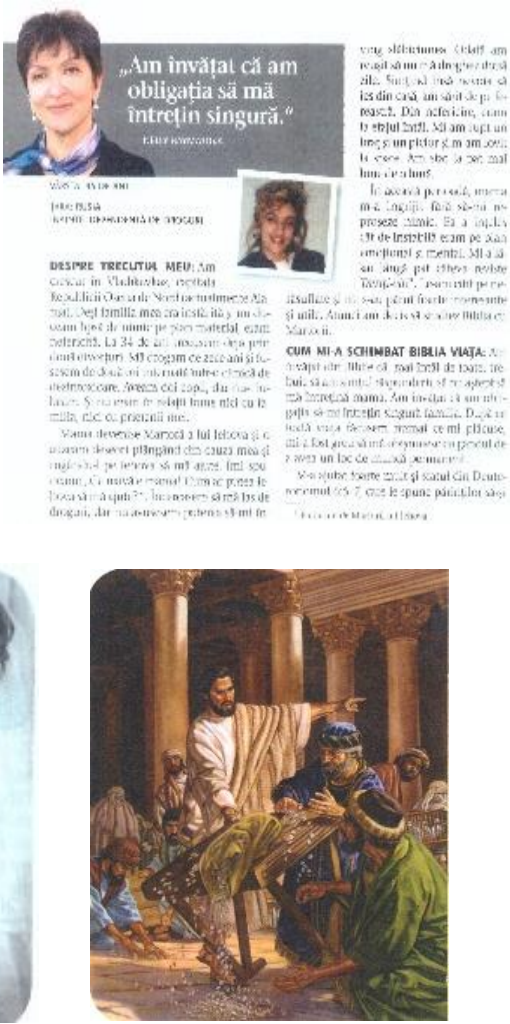
ARS LITURGICA. From the Image of Glory to the Images of the Idols of Modernity

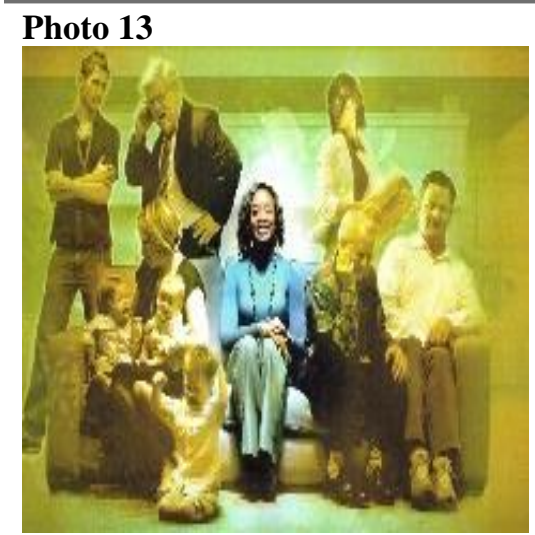

\section{Photo 14}

\section{Photo 15}
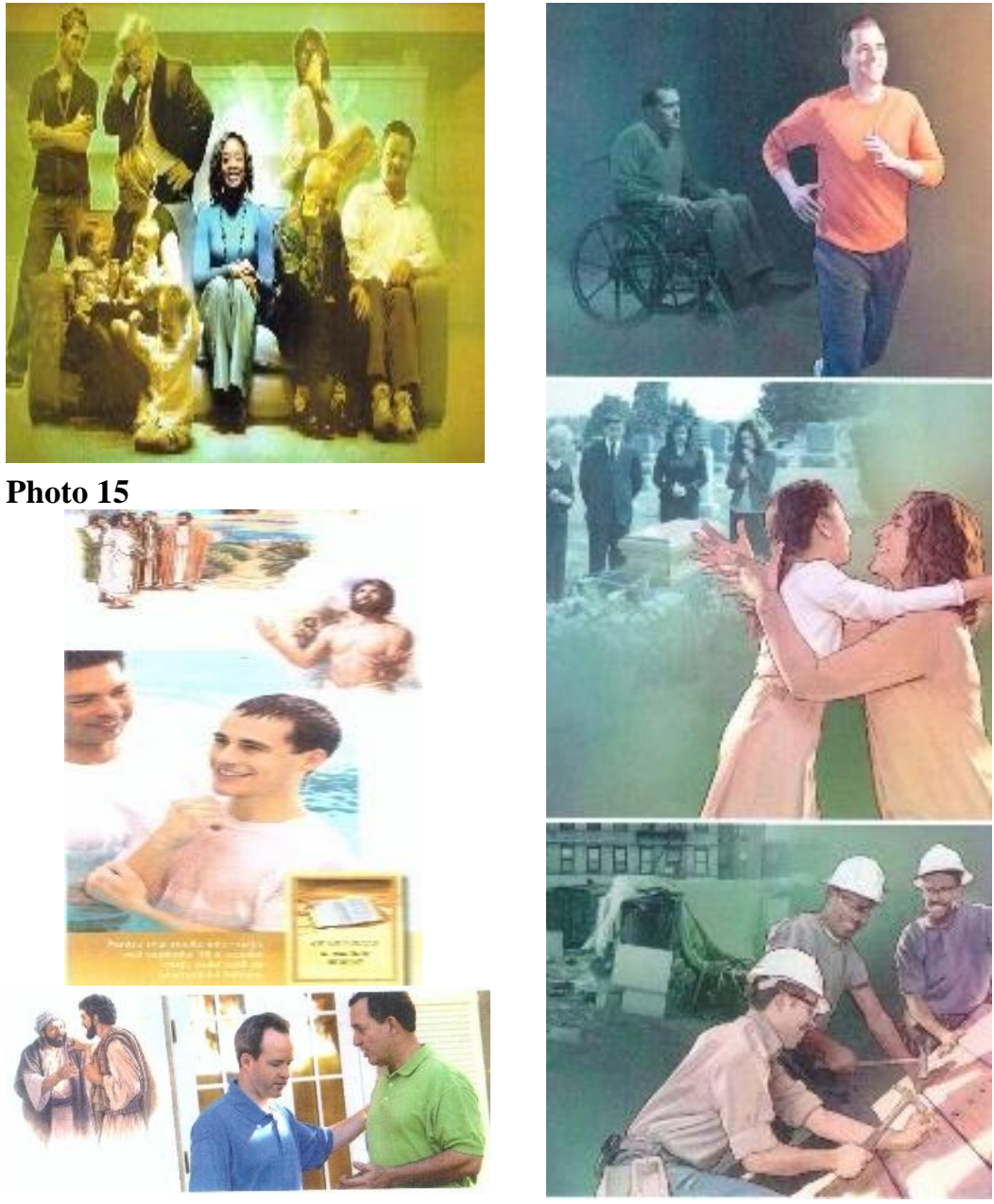

\section{Illustrations}

Photo 1: The Photo-drama of Creation (The Watchtower, February 1, 2014, p. 31 , study edition)

Photo 2: Why reject pornography? At https://www.jw.org/en/bible-teachings/ family/teenagers/ask/why-reject-pornography, (accessed April 22, 2017) 
Photo 3: My Bible Lessons (The Watchtower, May 1, 2012, p. 25)

Photo 4: Addressing the young (The Watchtower, December 1, 2015, cover image)

Photo 5: The Signes of the Times (The Watchtower, no. 2/ 2016, p. 12-13)

Photo 6: Should we Fear the End of the World? (The Watchtower, January 1m 2013, cover image)

Photo 7: The Armageddon's survivers (The Watchtower, May 1, 2015, cover image; The Watchtower, February 1, 2012, p. 7)

Photo 8: The Paradise on Earth (The Watchtower, September 1, 2010, p. 8)

Photo 9: The International Brotherhood (The Watchtower, March 1, 2015, cover image)

Photo 10: Teach your children! (The Watchtower, December 1, 2012, p. 30-31)

Photo 11: Bible changes lives (The Watchtower, August 1, 2010, p. 18)

Photo 12: The False Religion (Awake, June 2010, p. 22-23;)

Photo 13: The out and the inner world (The Watchtower, November 1, 2010, cover image)

Photo 14: The Utopian Paradise (The Watchtower, October 1, 2014, p. 6)

Photo 15: Mirror images (The Watchtower, May 2010, p. 16-17) 